\title{
Traditional protectionism versus behind-the-border barriers in the post-crisis era: experience of three groups of countries: the EU, NAFTA and BRICS
}

\author{
Marta Wajda-Lichy \\ Cracow University of Economics \\ Poland \\ wajdam@uek.krakow.pl
}

\begin{abstract}
This paper provides quantitative evidence of the protectionist measures implemented by three groups of countries: the European Union, NAFTA and BRICS in the aftermath of the last financial crisis. This article reveals that both emerging economies and highly-industrialized countries were very active in introducing discrimination measures against foreign commercial interests; however the dominated forms of protectionist actions were not traditional ones (border measures), but behind-the-border barriers. Furthermore, in the post-crisis era, the majority of protectionist actions took illegible form and were implemented not only towards the third countries but also among the members of free trade-based organization like the EU or NAFTA.
\end{abstract}

Received:

June, 2014

1st Revision:

Keywords: protectionism, trade policy, behind-the-border measures, global economic crisis, European Union, BRICS, NAFTA

JEL Classification: F13, F15, F53
September, 2014

Accepted:

October, 2014

DOI:

$10.14254 / 2071-$ $8330.2014 / 7-2 / 12$

\section{INTRODUCTION}

According to the conventional approach to foreign trade policy big trade collapse induces protectionist actions. It implies that protectionism is counter-cyclical. The consequences of the last financial crisis, which have spread to the global economy and triggered long-lasting slowdowns, bolstered a threat of introduction of new protectionism measures. A strong conviction about a return to protectionism induced some economists to monitor government's actions and verify their compliance with the pledges made in the framework of the World Trade Organization or other institutional entities like the European Union (EU). The traditional approach to protectionism based on stylized facts also suggests a stronger resort to trade discrimination in the case of developing and emerging economies with high level of openness. The objective of this paper is to examine the scale and forms of protectionist actions undertaken in the post-crisis era by three groups of countries: the BRICS which represents emerging economies (Brazil, Russia, India, South Africa), the EU and the NAFTA (the USA, Canada, Mexico), which in majority embrace advanced economies. Total share of the chosen economies in the world trade is significant and amounted to $63 \%$ in exports and $65 \%$ in global imports. The main source of data analysed in the paper come from the Global Trade Alert initiative affiliated with the Centre of Economic Policy Research (CEPR). The article revealed that not only emerging countries, but also governments of high-industrialized economies, were very active in implemen- 
tation of discrimination measures against foreign commercial interests in the aftermath of the last financial crisis. However, their activities were very often 'behind-the-border' which meant that protectionism took an illegible form and it became difficult to monitor and measure. The article also presents classification of 'behind-the-border' protectionist measures and tries to redefine the term of economic protectionism in the context of modern discrimination actions undertaken after the last global financial crisis.

This paper is organized as follows. Section I presents the scale of trade collapse in the world economy in 2009. This phenomenon is described with respect to long-term tendencies in international trade flows. Section II analyses the volume and scope of trade-policy measures implemented in the post-crisis era. It examines character of the measures and affected trading partners. Section IV focuses on forms of protectionist instruments including tariff, non-tariff, border and behind-the-border measures used by the EU, NAFTA and BRICS countries in the aftermath of the last global crisis. Section V concludes with implication of further areas of research.

\section{A SUDDEN TRADE COLLAPSE AS A CONSEQUENCE OF THE FINANCIAL CRISIS OF 2008}

Since the 1980s, a distinct long-term trend of increase in the level of trade openness can be clearly identified in the world economy. Trade openness can be calculated as a sum of exports and imports as a percentage of nominal gross domestic product $(\mathrm{GDP})^{1}$. Figure 1 shows the annual data for the world economy with differentiation between developing and developed economies.

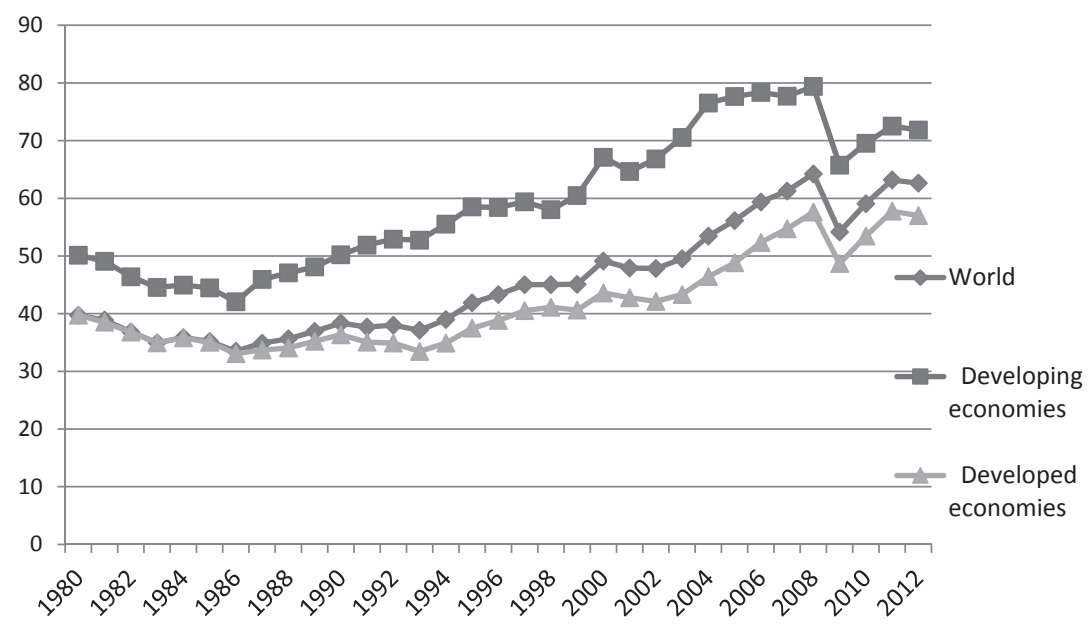

Figure 1. Goods and services trade openness as percentage of GDP, 1980-2012

Source: Data from UNCTAD, http://unctadstat.unctad.org/ReportFolders/reportFolders.aspx

1 Trade openness can be also calculated as an average of exports and imports as percentage of nominal gross domestic product (GDP). Average of imports and exports, which indicates the size of foreign trade, is calculated by adding imports and exports and then divided it by two. 
In 1980 developing countries registered a sum of exports and imports in relation to GDP at 50\% whereas a level of openness of developed countries was 40\%. Up to 2008 trade openness has increased respectively to $79 \%$ and $56 \%$. The last financial crisis, which caused a 'Great Recession' on a global scale, reduced not only production but also volume of exports and imports in the vast majority of economies. A collapse of trade flows exceeded a decline of output in both groups of countries so the indicators of trade openness for the majority of economies abruptly diminished in 2009 (see figure 1).

A quick recovery in international trade occurred in 2010 and 2011, but in 2012 and 2013 trade growth was sluggish. Figure 2 shows growth rates of merchandise exports and imports in three groups of countries: BRICS, EU and NAFTA. After a sudden bust in 2009 when world exports shrank by $22 \%$ compared to the level of the previous year, exports of BRICS countries grew by 36\% in 2010. Rates of export growth in 2010 were also high in EU and NAFTA, respectively $12 \%$ and $22 \%$. These data reflect the general trend of international trade recovery because in 2010 exports of developing countries grew by around 29\% and 16\% in the case of developed economies. Annual growth rates of imports in 2010 were even higher and amounted to $30 \%$ in developing countries and $17 \%$ in developed economies.

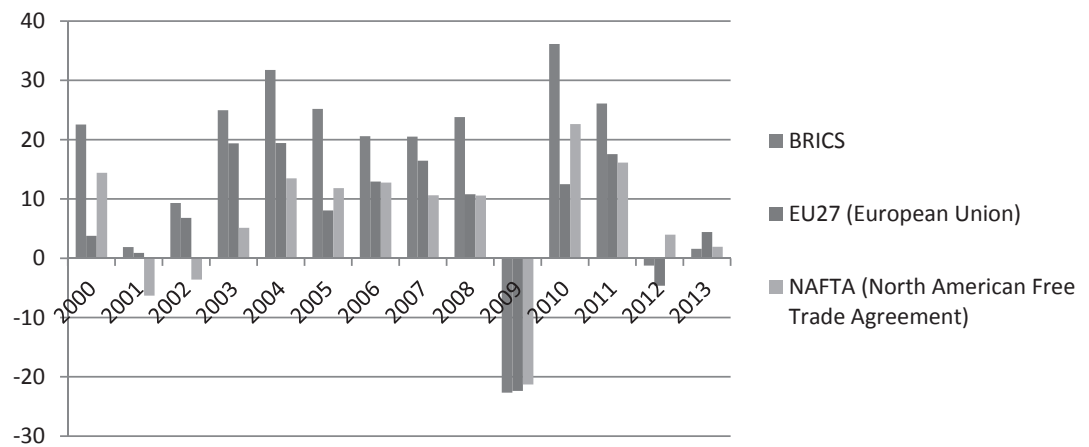

Figure 2. Annual value growth rates of merchandise exports, 2000-2013 (as \%)

Source: Data from UNCTAD, http://unctadstat.unctad.org/ReportFolders/reportFolders.aspx

Rapid recovery of international trade continued in 2011 but in 2012 and 2013 the growth rates of exports and imports were either negative or very small (see figure 2). It is worth noting that after the 'Great Recession' as well as before the last crisis, emerging economies, including BRICS countries, registered significantly higher rates of export growth compared to the EU and the NAFTA countries. This phenomenon can be explained by the strong position of emerging economies in the global-value-chain production system.

One of the consequences of the last global crisis was a change of shares of particular countries in the world trade. Figure 3 shows that the international positions of the EU and NAFTA countries have steadily weakened since 2004 whereas the share of BRICS countries in the world exports increased to 18\% in 2013. These tendencies reflect the long-term loss of competitiveness of the EU and NAFTA countries and the gain in the upper position in international trade by emerging markets ${ }^{2}$. The above characteristics imply that in

2 The increase in the share of developing countries (including BRICS) in the world exports has been mainly due to China economy which share in global exports in 2000 was around 4\% whereas in 2013 it amounted to nearly 12\% (Data: UNCTADstats, 2014). 
the face of the 'Great Recession' and the global trade slump developed countries could have resorted to trade barriers even more than developing economies.

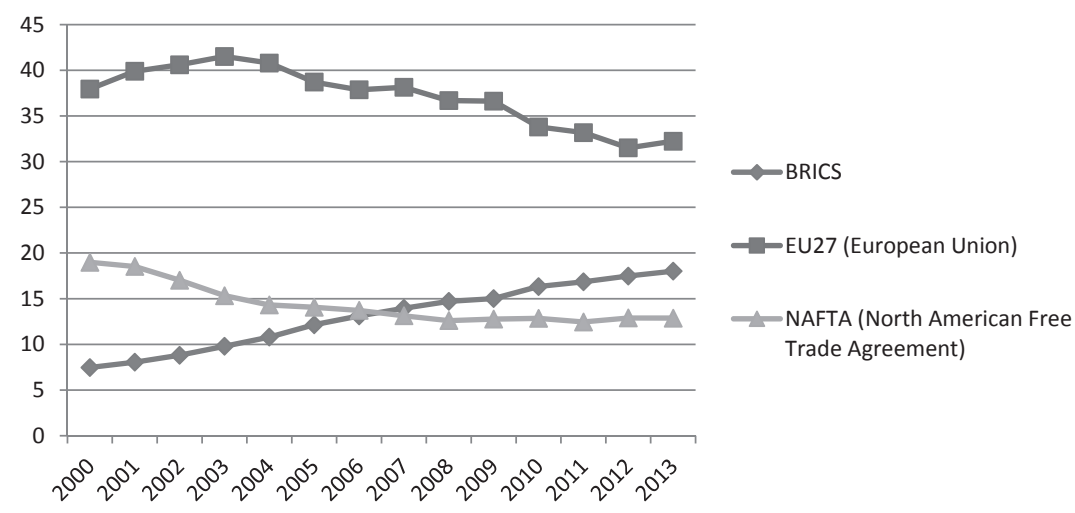

Figure 3. Shares of the EU, NAFTA and BRICS countries in world exports, 2000-2013 (as \%) Source: Data from UNCTAD, http://unctadstat.unctad.org/ReportFolders/reportFolders.aspx

The global crisis provoked not only the sudden fall of exports (negative external shock), but also roughly restrained import purchases. This implied that the final effects for trade balance was ambiguous. In 2009 the majority of economies registered a deterioration in their trade balances (e.g. China, Russian Fed., Brazil, Canada) but some economies (e.g. USA, Mexico) reduced their trade deficits or even increased surpluses (e.g. the EU as a whole). Figure 4 presents trade balances as percentage of GDP for countries of BRICS, the EU (as a whole) and the NAFTA.

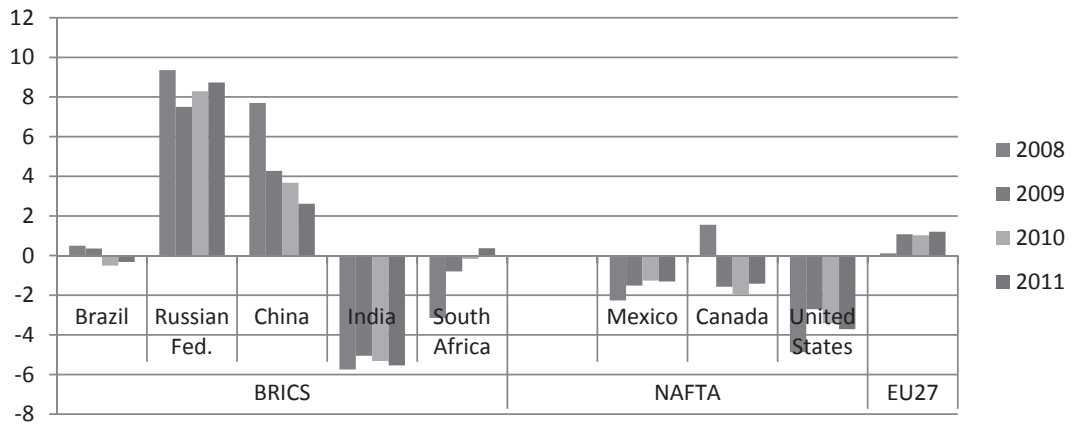

Figure 4: Trade balances as percentage of GDP, 2000-2012

Source: Data from UNCTAD, http://unctadstat.unctad.org/ReportFolders/reportFolders.aspx

In the case of countries, which in 2009 were severely hit by negative demand shock and suffered from the loss of international competitiveness, trade imbalances could act as a spur to introduce protectionist measures. 


\section{THE SCALE AND SCOPE OF PROTECTIONIST MEASURES IMPLEMENTED IN THE POST-CRISIS ERA}

Since the last global economic crisis outbreak, many governments have implemented different measures to deal with the consequences of the slowdown and to stimulate their economies. Trade policy was one of the dynamic areas of government activities. Figure 5 shows that in the case of all three analysed groups of countries (EU, NAFTA and BRICS) the number of trade restrictiveness measures significantly exceeded the number of trade liberal or neutral actions. Figure 5 indicates that the number of harmful measures which are classified by the Global Trade Alert as 'red' or 'amber' ${ }^{3}$ implemented by the BRICS countries was the highest (781) among the considered bloc countries, whereas in the NAFTA economies had the lowest (292). Taking into consideration trade-liberal or trade-neutral measures ${ }^{4}$, net result is negative for all three groups of countries, however the number of harmful measures as a percentage of total implemented measures by each group is the highest for the EU countries - amounting to $86 \%$ (see figure 5), whereas for BRICS countries it amounts to $67 \%$ and for NAFTA economies to $64 \%$. These results indicate that the EU countries trade actions in the post-crisis era were the most restrictive compared to other analysed groups of countries.
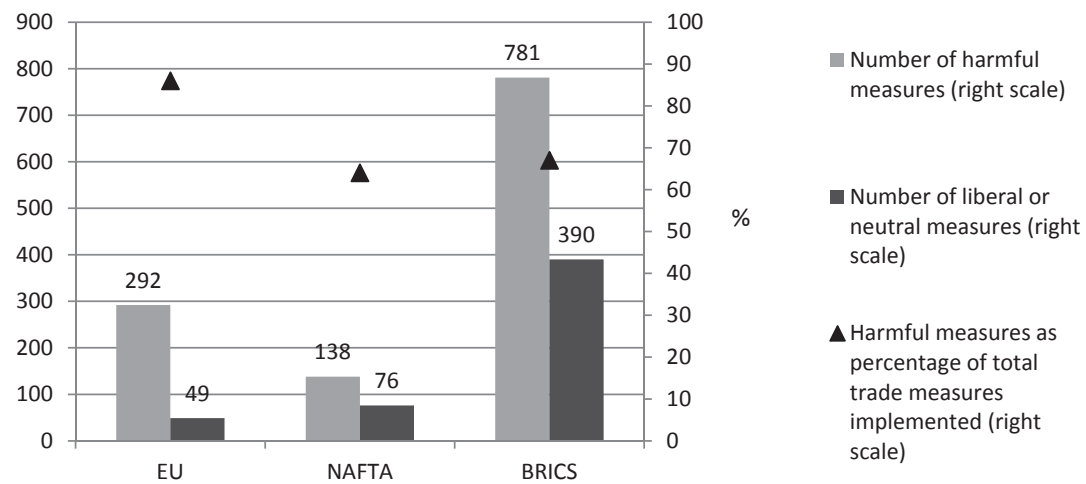

$\Delta$ Harmful measures as percentage of total trade measures implemented (right scale)

Figure 5. Number of trade policy measures implemented in the period 2008-2013

Source: Author's calculations based on the Global Trade Alert database, http://www.globaltradealert.org/site-statistics

Another interesting phenomenon concerning the scale and scope of protectionism refers to trading partners affected by trade-discriminating measures implemented by the countries belonging to the considered three groups. In particular the question arises whether protectionist actions have been applied mainly towards the third countries (outside the group) or whether they were used also against other members of the bloc. This issue is particularly related to free trade agreement set between Canada, Mexico and the USA, as well as to the EU countries operating in a common market. The BRICS countries have not established any formal agreement of economic cooperation, nevertheless they were involved in the research.

\footnotetext{
3 According to Global Trade Alert classification 'red' colour indicates the measures implemented which almost certainly discriminate against foreign commercial interest. 'Amber' refers to the measures implemented which may indicate discrimination or announced and almost certainly involves discrimination against foreign commercial interest.

4 Liberal or neutral measures are classified by Global Trade Alert as 'green'. They involve liberalization or have been found not to be discriminatory.
} 
The top 10 trading partners mostly affected by protectionist measures implemented by the EU, NAFTA and BRICS countries

\begin{tabular}{|c|c|c|c|}
\hline \multirow{2}{*}{$\begin{array}{c}\text { Implementing } \\
\text { jurisdiction }\end{array}$} & $\begin{array}{c}\text { EU } \\
\text { countries }\end{array}$ & NAFTA countries & BRICS countries \\
\hline \multirow{4}{*}{$\begin{array}{c}\text { Affected trading } \\
\text { partner }\end{array}$} & China & China & China \\
\cline { 2 - 4 } & USA & USA & Germany \\
\cline { 2 - 4 } & Germany & Mexico & USA \\
\cline { 2 - 4 } & France & France & France \\
\cline { 2 - 4 } & India & UK & Italy \\
\cline { 2 - 4 } & Belgium & India & Japan \\
\cline { 2 - 4 } & The United Kingdom & Philippines & Netherlands \\
\cline { 2 - 4 } & Italy & Japan & Thailand \\
\cline { 2 - 4 } & Netherlands & Germany & Poland \\
\hline
\end{tabular}

Source: Data from of the Global Trade Alert, http://www.globaltradealert.org/site-statistics

Data in table 1 revealed that in terms of the number of times that commercial interests have been discriminated against, China is listed at the top by all considered jurisdictions. In the case of BRICS countries, India and Russia were particularly active in implementing trade measures against Chinese commercial interest. Foreign protectionist measures have been also very often used against the USA market agents. According to the data presented in table 1, the USA was listed at the second position in the ranking of economies the most frequently affected by protectionism measures applied by both the EU and the NAFTA countries. It is surprising that two of the NAFTA member economies, the USA and Mexico, were ranked respectively on the second and third position in the top-10 list of economies harmed by the NAFTA countries. ${ }^{5}$ This means that the commitments to avoid protectionism made by the members of free trade area were not fulfilled, although article 102 of the NAFTA declaration stipulates that 'The objectives of this Agreement, as elaborated more specifically through its principles and rules, including national treatment, most-favored-nation treatment and transparency, are to: a) eliminate barriers to trade in, and facilitate the cross-border movement of, goods and services between the territories of the Parties; b) promote conditions of fair competition in the free trade area [...] (North American Free Trade Agreement).

It is worth noting that the weakness of fulfilling the pledges to free trade rules refers also to the EU countries. As table 1 shows Germany, France, Belgium, the United Kingdom, Italy and Spain are positioned at the top-10 list of trading partners affected by the EU countries. The fact that so many EU members were discriminated against by other Common Market economies implies the possibility of circumvention of the binding free-trade regulations. These rules are set in the Treaty on the Functioning of the European Union (TFEU), part III Union Policies and Internal Actions. Article 30 of the TFEU says that 'Customs duties on imports and exports and charges having equivalent effect shall be prohibit between Member States. This prohibition shall also apply to customs duties of a fiscal nature'. Article 34 of the TFEU certifies that 'Quantitative restrictions on imports and all measures having equivalent effect shall be prohibited', whereas article 35 of the TFEU refers to export measures and stipulates that 'Quantitative restrictions on exports, and all measures having equivalent effect, shall be prohibited'. However, it should be mentioned that article 36 of the TFEU gives

5 Canada was listed at the 12 position in terms of trading partners most often harmed by the NAFTA countries. 
legal opportunities for introducing some protectionist measures as it says that 'The provisions of Articles 34 and 35 shall not preclude prohibitions or restrictions on imports, exports or goods in transit justified on grounds of public morality, public policy or public security; the protection of health and life of humans, animals or plants; the protection of national treasures possessing artistic, historic or archaeological value; or the protection of industrial and commercial property. Such prohibitions or restrictions shall not, however, constitute a means of arbitrary discrimination or a disguised restriction on trade between Member States'. Although the above cited articles regulate the common trade policy, they mainly refer to trade barriers, so in the post-crisis era, the EU members used mainly behind-the-border protectionist measures.

\section{FORMS OF PROTECTIONIST MEASURES IMPLEMENTED BY THE EU, NAFTA AND BRICS COUNTRIES AFTER 2008}

As during the two decades preceding the crisis many countries made efforts to eliminate trade barriers (mainly tariffs), and the range of trade defence measures seemed to be limited for those who wanted to fulfil their treaty pledges. Nevertheless, protectionist actions undertaken in the aftermath of the crisis were rich in implementing new export-led-growth and import impediment measures. It is worth noting that the forms of implemented protectionist measures differed among the analysed economies but in all three groups nontariff instruments distinctly dominated over the tariff measures.

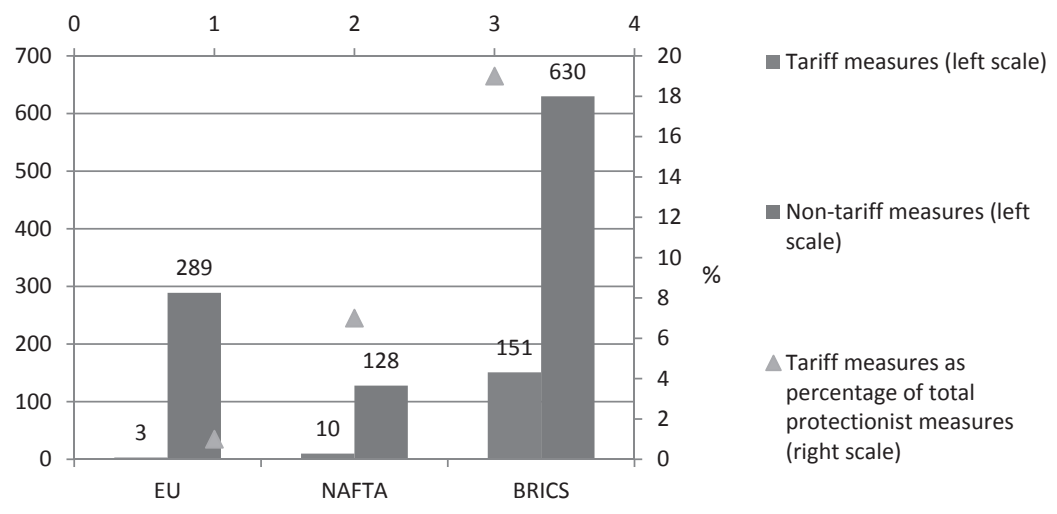

Figure 6: Number of tariff and non-tariff harmful measures implemented in the aftermath of the global crisis, 2008-2013

Source: Author's calculations based on the Global Trade Alert database, http://www.globaltradealert.org/site-statistics

As figure 6 shows the EU countries which according to customs union rules have common trade tariffs and for the two last decades have been very active in promoting trade liberalization increased tariffs only three times, what constituted around $1 \%$ of all restrictive measures implemented by the EU economies. The NAFTA countries were also muted in using tariffs (7\% of all protectionist measures). However, for the BRICS countries, tariffs were the most popular protectionist instruments, as they amounted to $19 \%$ of total protectionist measures implemented by the countries of this group (see figure 6 and figure 9). The reason for this refers to the fact that many developing countries did not participate in official tariff cutting in the post-war GATT rounds. Their late involvement to multilateral liberalization process made their tariff level 
higher comparing with advanced economies. The point is that as developing countries have negotiated with the WTO higher bound tariffs - i.e. the tariff ceilings, their applied tariffs could rise up to the bound level without offending the WTO obligations. For example, Brazil has negotiated final bound tariff rates at $31,4^{6}$ whereas the applied tariff rates in 2012 amounted to 13,5. In the case of India bound tariffs were set at 48,6 , whereas the applied tariffs for all goods amounted to 13,7 . It is worth noting that the final bound tariffs for agriculture goods were negotiated at 113,1 and tariffs actually imposed by India reached 34,4. The bound rates for advanced economies as well as the level of applied tariffs by this group of countries were significantly lower. For example, the bound tariffs in the USA and Canada were set at 3,5 and 6,9, whereas the actually charged duties amounted in 2012 respectively to 3,4 and 4,3. For the EU countries the average of applied import duties exceeded by 0,3 p.p. the bound level set at 5,2 (WTO, 2014). As it can be easily noticed not only tariff level but also the differences between the bound and applied tariffs are distinctly lower in advanced economies than in developing countries. This restricts developed economies to increasing the import duty rates.

At the beginning of the post-crisis era the majority of researchers trying to explain trade barriers' impact on the trade collapse in 2009 defined protectionism as border measures such as tariffs, quotas, import bans and export taxes (Bown, Crowley 2012; Knee, Neagu, Nicita 2013). The reason for a common use of boarder measures to assess the role of protectionism on international trade collapse was due to limitations of behind-the-border data. With time more and more economists admitted that other policy measures, such as government bailouts, buy-national requirements, public procurement or technical standards could play a much larger role than tariffs and antidumping duties in affecting trade during the last financial crisis (Evenett, Vines 2012; Baldwin, Evenett 2012; Kee, Neagu, Nicita 2013). Great economic significance of non-tariff barriers was confirmed also by WTO, UNCTAD, OECD, as well as political initiatives like G-20 summits which at the height of the crisis started to discuss and monitor protectionist and discrimination actions undertaken as a reaction to a global crisis. Their initiatives were new with respect to examining some of the policy instruments as behind-the-border measures.

Behind the border barriers refers to a variety of non-tariff barriers that operate inside countries rather than at the border, but that nonetheless can restrict or discriminate trade. Examples include technical barriers to trade, subsidies to exporters, administrative regulations concerning public procurement, sanitary and phytosanitary regulations as well as so called 'green protectionism' measures. It is worth noting that behind-the-border measures are related to requirements and regulations imposed before export dispatch or import purchase and they often concern either intangible products or services which do not pass the border. Baldwin, Evenett and Low (2007) list six areas of behind-the-border measures: trade in services, government procurement, competition policy, investment performance measures, technical barriers to trade, and trade remedies. It should be underlined that the term 'non-tariff measures' is broader than 'behind the border barriers' because the former one alters the conditions of international trade, including ones that act to increase trade as well as those that restrict it whereas the previous one mainly impedes trade. However, the two are sometimes used interchangeably, e.g. anti-dumping duties which generally are classified as border measures can be treated as non-border barriers because as Staiger (2012, p. 8) confirmed referring to research of Staiger and Wolak from 1994, 'antidumping claims can significantly reduce trade flows during the period of investigation of these claims, even though no antidumping duties are in place over the period of investigation and even if the investigation ends in a finding of no dumping and no duties are ever imposed.

6 The bound rates and the applied tariffs are given as simple average of import duties. 


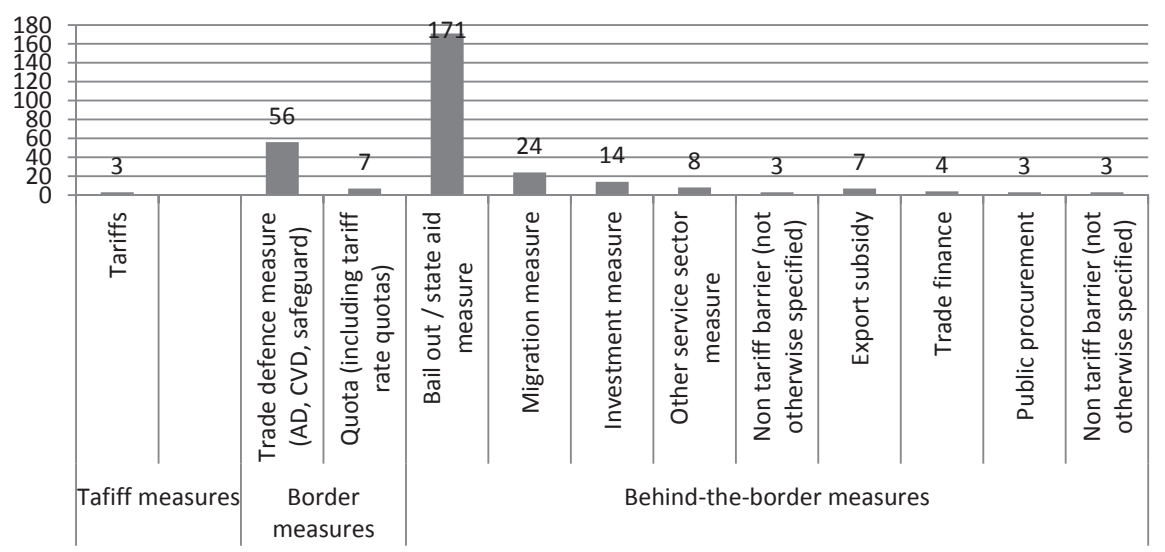

Figure 7: Number of specified protectionist measures implemented by the EU countries, 2008-2013

Source: Data from the Global Trade Alert database, http://www.globaltradealert.org/site-statistics

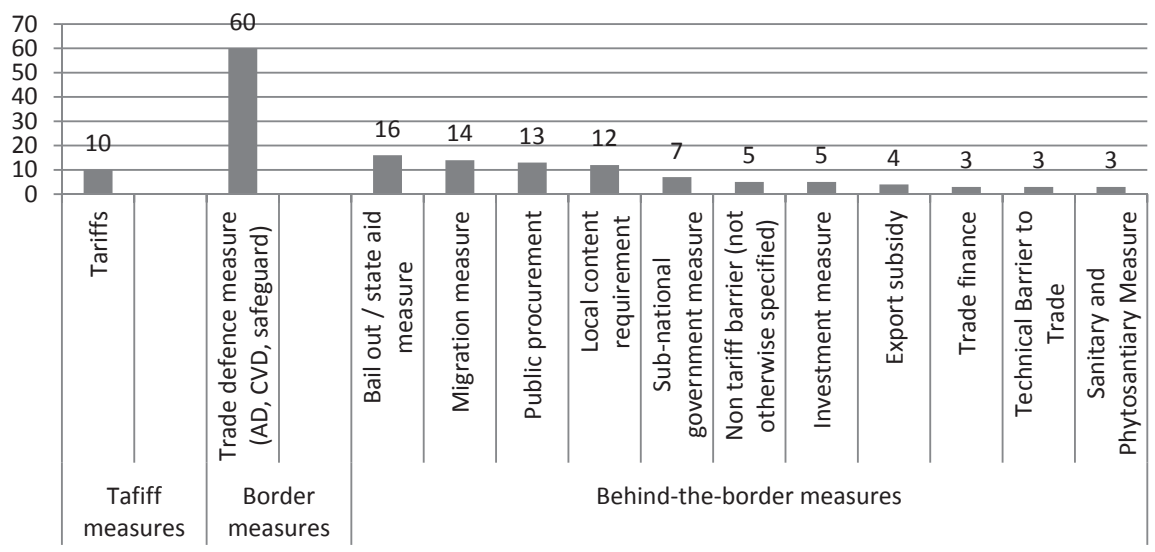

Figure 8: Number of specified protectionist measures implemented by the NAFTA countries, 2008-2013

Source: Data from the Global Trade Alert database, http://www.globaltradealert.org/site-statistics 


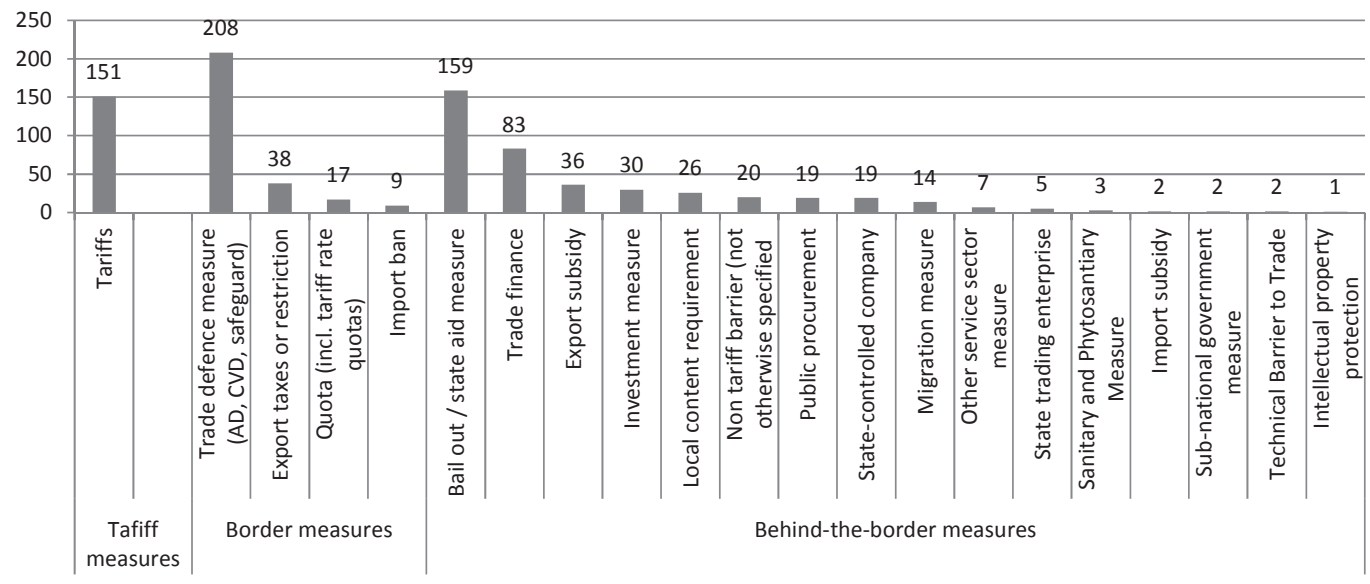

Figure 9: Number of specified protectionist measures implemented by the BRICS countries, 2008-2013

Source: Data from the Global Trade Alert database, http://www.globaltradealert.org/site-statistics

Figures 7, 8 and 9 present number of specified protectionist measures implemented by the EU, NAFTA and BRICS countries with regard to three groups of protectionist measures: tariffs, non-tariff border measures and behind-the-border instruments. Border measures comprise: anti-dumping duties (AD), countervailing duties, safeguards, quotas and import bans. The list of behind-the-border measures is longer and includes among others: bail out/state aid measures, public procurement, trade finance, export subsidies, investment and migration measures and local content requirements. As shown, tariffs were not popular trade defence instrument, except the BRICS countries. In all considered three groups of countries non-tariff instruments distinctly exceeded the number of traditional tariffs measures. Furthermore, the EU, NAFTA and BRICS countries used particularly often such behind-the-border measures like bail-out/state aid. In the case of the EU and NAFTA, migration restraints were ranked on the second position, whereas for BRICS countries they were not the primary protectionist instruments. Total number of behind-the-border measures amounted to 428 for the BRICS countries, 237 for the EU countries and 85 for the NAFTA economies. These results exceeded the non-tariff border measures which amounted respectively to 272, 63 and 60 .

\section{CONCLUSIONS}

The decline of the volume of world international trade in 2009 as well as a time-lag recovery of global output increased threat of a return to protectionist measures. The aim of this paper was to evaluate the scale and scope of protectionist measures implemented by three groups of countries (the EU, NAFTA and BRICS) in the aftermath of the last financial crisis. The key results revealed that both developing and developed countries have implemented new protectionist measures since 2008. However, to not offend against official pledges declared in the framework of bilateral or multilateral agreements, the majority of examined countries resorted rather to behind-the-border measures. Baldwin and Evenett (2009) called this a 'murky protectionism'. 
With respect to the forms of behind-the-border measures, bail-out and state aid were the most often used instruments, whereas anti-dumping duties $(\mathrm{AD})$, countervailing duties and safeguards dominated as border but non-tariff measures. Tariffs constituted only $1 \%$ of all restrictive measures implemented by the EU economies and $7 \%$ in the case of the NAFTA countries. However, for the BRICS countries tariffs amounted to $19 \%$ of total number of protectionist instruments implemented by this group. This was due to quite a lot of leeway, which was allowed to many developing countries according to the WTO negotiation rules. The point is that as developing countries have negotiated with the WTO higher than advanced economies bound tariffs- i.e. the tariff ceilings, their de facto applied tariffs could rise up to the bound level without offending the WTO obligations.

In terms of trading partner affected, China tops the list of the countries the most often harmed by all of the examined jurisdictions. Another finding is that protectionist measures were often implemented against commercial interest of other members of the examined groups, e.g. among the EU or NAFTA members. These facts proved that despite free trade agreements and common market rules the governments left space for circumvention of the binding free-trade regulations. The wide range of behind-the-border measures including public procurement or safety standards very often refer to intangible goods and services what makes them less transparent and difficult to quantify. That is why the economist tried to construct new indicators of protectionism comprising non-direct measures which could better inform discriminating actions and help to deter the countries form beggar-thy-neighbour acts.

\section{REFERENCES}

Baldwin R., Evenett S.J. (2009), Don't let murky protectionism stall a global recovery: Things the G20 should do, http:// www.voxeu.org/article/

Baldwin R., Evenett S.J., Low P. (2007), Beyond Tariffs: Multilaterising Non-Tariff RTA Commitments, http://graduateinstitute.ch/files/live/sites/iheid/files/sites/ctei/shared/CTEI/Baldwin/Publications/Chapters/Regionalism/Beyond $\% 20$ tariffs $\% 20$ multilateralising $\% 20$ non $\% 20$ tariff\%20RTA $\% 20$ commitments.pdf

Baldwin R., Evenett S. J. (2012), Beggar-thy-neighbour policies during the crisis-era: causes, constraints and lessons for maintaining open borders, Oxford Review of Economic Policy, Vol.28 no 2.

Bown Ch. P., Crowley M. A. (2013), Import protection, business cycles, and exchange rates: Evidence from the Great Recession, Journal of International Economics 90.

Evenett S. J., Vines D. (2012), Crisis-era protectionism and the multilateral governance of trade: an assessment, Oxford Review of Economic Policy, Vol.28 no 2.

Global Trade Alert database, http://www.globaltradealert.org/site-statistics

Kee H. L., C. Neagu, A. Nicita (2013), Is protectionism on the rise? Assessing national trade policies during the crisis of 2008, The Review of Economics and Statistics, March 2013

North American Free Trade Agreement, http://www.naftanow.org/default_en.asp

Staiger R. W. (2012), Non-Tariff Measures and the WTO, Staff Working Paper, WTO, January 2012, http://www.wto. org/english/res_e/reser_e/ersd201201_e.pdf Staff Working Paper ERSD-2012-01

Treaty on the Functioning of the European Union, consolidated version, Official Journal of The European Union, C326/47

WTO (2014), WTO statistics, http://stat.wto.org/CountryProfile

UNCTAD, http://unctadstat.unctad.org/ReportFolders/reportFolders.aspx

WTO, World Trade Report 2012, http://www.wto.org/english/res_e/booksp_e/anrep_e/wtr12-2d_e.pdf 